\title{
Sex Difference in PCB Concentrations of a Catostomid Fish
}

\author{
Charles P Madenjian ${ }^{1 *}$, Andrew L Stevens ${ }^{2}$, Martin A Stapanian ${ }^{3}$, Stuart A Batterman ${ }^{4}$, Sergei M Chernyak ${ }^{4}$, Jordan E Menczer ${ }^{4}$ and Peter B \\ Mclntyre ${ }^{5}$ \\ ${ }^{1}$ US Geological Survey, Great Lakes Science Center, Ann Arbor, Michigan, USA \\ 2US Fish and Wildlife Service, Ashland Fish and Wildlife Conservation Office, Ashland, Wisconsin, USA \\ ${ }^{3}$ US Geological Survey, Great Lakes Science Center, Lake Erie Biological Station, Sandusky, Ohio, USA \\ ${ }^{4}$ School of Public Health, University of Michigan, Ann Arbor, Michigan, USA \\ ${ }^{5}$ Center for Limnology, University of Wisconsin, Madison, Wisconsin, USA
}

\begin{abstract}
Unraveling the complexities associated with the relative differences in contaminant concentrations between the sexes of mature fish may provide insights into important behavioral and physiological differences between the sexes of not just fish but higher vertebrates as well. Whole-fish polychlorinated biphenyl (PCB) concentrations were determined in 25 mature female white suckers (Catostomus commersoni) and 26 mature male white suckers caught during their spawning run in the Kewaunee River, a tributary to Lake Michigan. Total length and weight were measured for each fish, and age of each fish was estimated from thin-sectioned otoliths. PCB concentration significantly increased with increasing total length, weight, and age. Consequently, three analysis of covariance (ANCOVA) models were fitted to the data to assess the effect of sex on white sucker PCB concentration. Based on model averaging, estimates of mean PCB concentrations in female and male white suckers were 185 and $219 \mathrm{ng} / \mathrm{g}$, respectively. Thus, males were $18 \%$ greater in PCB concentration than females. We conclude that this difference between the sexes was most likely mainly driven by a higher rate of energy expenditure in males compared with females. Greater energy expenditure, owing to greater swimming activity and a higher resting metabolic rate, resulted in a higher rate of food consumption, which in turn led to a greater rate of PCB accumulation. Higher whole-fish PCB concentration in males compared with females has now been shown in nine different fish species. Our study represented the first documentation of this type of sex difference in a catostomid fish.
\end{abstract}

Keywords: Catostomids; Fish consumption advisories; PCBs; Sex differences; White sucker

\section{Introduction}

Males exceeding females in whole-fish polychlorinated biphenyl (PCB) concentration appears to be an emerging pattern in toxicology [1]. This sex difference has been mainly attributed to a higher rate of energy expenditure in mature males compared with mature females, although the growth dilution effect may make a substantial contribution to this difference in some fish populations in which females grow substantially faster than males. Both a higher resting metabolic rate in males and greater swimming activity by males contribute to the higher energy expenditure rate in males. As a consequence of this higher rate of energy expenditure, males need to feed at a higher rate compared with females to attain the same size as females. Given that the predominant pathway of entry of PCBs into a fish's body is via food intake [1,2], a higher rate of food consumption leads to a higher rate of PCB accumulation. This pattern of a higher rate of energy expenditure in males compared with females appears to also pertain to higher vertebrates as well as fish [1].

A commonly used explanation for males exceeding females in PCB concentration of fishes has been that PCB concentration in females markedly drops due to release of eggs, but Madenjian et al. [1] provided evidence to support dismissal of this hypothesis. First, both coho salmon (Oncorhynchus kisutch) and sea lamprey (Petromyzon marinus) are semelparous species in that they spawn only once during their lifetime and die soon thereafter. Determinations of PCB concentrations in both coho salmon and sea lamprey caught prior to spawning showed that males exceeded females in PCB concentration by $17-19 \%$. Release of eggs at spawning could not possibly account for the observed higher PCB concentrations in males, because all of the PCB determinations were on fish that had never previously spawned. Second, PCB determinations in both the eggs and somatic tissue of fishes have indicated that for most species of fish, PCB concentrations of females actually increase, rather than decrease, immediately after spawning. An increase in PCB concentration of females immediately after spawning could not possibly explain the higher PCB concentrations in males compared with females. After testing several hypotheses, Madenjian et al. [1] concluded that the most likely primary driver of the sex difference in PCB concentrations was that males expended energy at a higher rate than females.

White sucker (Catostomus commersoni) is regarded as a sentinel species for environmental degradation of aquatic habitats [3-9], fulfills an important ecological role of transferring nutrients between aquatic ecosystems [10], and, as a member of the family Catostomidae, is ecomorphologically specialized for feeding on benthic algae and other plant material, as well as benthic macroinvertebrates [5,11]. White sucker is abundant and widely distributed across North America, is a benthic species, shows site fidelity to its spawning area, and exhibits fidelity to a home range at times of the year other than spawning time. Thus, this species is well suited as a sentinel of contaminated sediments [3-9]. Moreover, loss of connectivity between habitats due to construction of dams can drastically affect white sucker abundance in human-altered aquatic ecosystems by separating the adult white sucker population from its preferred spawning areas $[5,10]$. During spring, huge numbers of white suckers migrate from larger bodies of water into

*Corresponding author: Charles P Madenjian, US Geological Survey, Great Lakes Science Center, Ann Arbor, Michigan, USA, Tel: 7342147259; Fax: 7349948780; E-mail: cmadenjian@usgs.gov

Received October 03, 2017; Accepted October 09, 2017; Published October 14, 2017

Citation: Madenjian CP, Stevens AL, Stapanian MA, Batterman SA, Chernyak SM, et al. (2017) Sex Difference in PCB Concentrations of a Catostomid Fish. J Environ Anal Toxicol 7: 515. doi: 10.4172/2161-0525.1000515

Copyright: (c) 2017 Madenjian CP, et al. This is an open-access article distributed under the terms of the Creative Commons Attribution License, which permits unrestricted use, distribution, and reproduction in any medium, provided the original author and source are credited. 
small tributaries to spawn, thereby transferring nutrients across aquatic ecosystems [10]. Thus, the white sucker serves a key ecological function of providing important nutrient subsidies to stream ecosystems. Adult white suckers are omnivorous, typically feeding on benthic algae, including diatoms and desmids, and other plant material, as well as benthic macroinvertebrates, especially chironomids $[8,12,13]$.

Documentation of higher $\mathrm{PCB}$ concentration in mature male white suckers compared with mature female white suckers would mark an important step in establishing the degree of prevalence of males exceeding females in PCB concentration in fish populations around the world, which is one of the recommended future research directions for the field of sex differences in contaminant concentrations of fish [1]. To date, males have been shown to be higher in whole-fish PCB concentration than females in walleye (Sander vitreus), lake trout (Salvelinus namaycush), coho salmon, burbot (Lota lota), sea lamprey, cisco (Coregonus artedi), lake whitefish (Coregonus clupeaformis), and summer flounder (Paralichthys dentatus). Relative differences in PCB concentrations between the sexes have ranged from $17 \%$ to $43 \%$. However, to the best of our knowledge, sex differences in PCB concentrations of catostomid fishes have yet to be investigated. Further, none of the eight above-mentioned fish species are considered omnivorous [1], and therefore our investigation into white sucker ecology would be the first ever of its kind for an omnivorous fish.

The overall goals of our study were to characterize the sex difference in whole-fish PCB concentrations of a white sucker population, and then identify the most likely cause or causes for the observed difference. Specific objectives included: (1) determine whether whole-fish PCB concentration in Lake Michigan adult white suckers that use the Kewaunee River for spawning was significantly affected by total length, weight, condition, age, or lipid concentration of the white suckers, (2) quantify the difference in whole-fish PCB concentrations between the sexes of these white suckers from Lake Michigan, (3) discuss the potential causes for the observed sex difference in PCB concentrations, and then identify the most likely cause or causes, and (4) discuss the implications of our findings with regard to the fish consumption advisories for Lake Michigan white suckers based on observed PCB concentrations. The ultimate aim was to determine whether the white sucker results continued to support the emerging pattern of higher $\mathrm{PCB}$ concentrations in males compared with females.

\section{Methods}

\section{Field methods}

On 19 April 2016, dip nets were used to catch 25 female and 26 male adult white suckers just below the dam at the C. D. "Buzz" Besadny Anadromous Fish Facility located on the Kewaunee River (Wisconsin, USA), a tributary to Lake Michigan. Gonads of all fish were in ripe condition, as gametes were observed while handling fish. Further, males exhibited nuptial tubercles on their anal and caudal fins. Thus, sex was easily determined in the field. The American Fisheries Society's guidelines for care and use of fishes were followed in handling the white suckers [14]. All fish were euthanized with tricaine methanesulfonate (MS-222) after capture. Total length (TL) of each fish was measured to the nearest $\mathrm{mm}$, and each fish was weighed to the nearest g. Otoliths were extracted from each fish for aging. Fish were frozen at $-20^{\circ} \mathrm{C}$, and then transported to the Great Lakes Science Center (GLSC) in Ann Arbor, Michigan for further processing.

\section{PCB, lipid, and age determinations}

At the GLSC, each of the 51 white suckers was partially thawed and then homogenized using appropriately sized blenders. For each white sucker, approximately $100 \mathrm{~g}$ of the whole-fish homogenate was placed in a contaminant-free glass jar, sealed with a lid, and stored at $-20^{\circ} \mathrm{C}$. Upon completion of the homogenization of all 51 white suckers, frozen homogenates were transported to the University of Michigan School of Public Health for PCB and lipid determinations.

Methods for the PCB and lipid measurements have been previously described [15-18]. In summary, starting with a 10-g sample of each homogenized whole fish, the organic fraction was extracted by repeated dichloromethane/hexane extractions, fractionated by three sequential elutions through florisil, concentrated to $1 \mathrm{ml}$ under a nitrogen stream, and the lipid fraction removed using sulfuric acid [19]. Analysis was performed using gas chromatography/mass spectrometry (5890/5973, Agilent Industries, Palo Alto, CA, USA), a splitless $2 \mu \mathrm{L}$ injection on a DB5-MS capillary column $(30 \mathrm{~m}$; inner diameter $0.25 \mathrm{~mm}$; film thickness $0.25 \mu \mathrm{m}$, J\&W Scientific, Folsom, CA, USA), helium as the carrier gas, methane as the mass spectrometer reagent gas, and negative chemical ionization selective ion monitoring mode. The gas chromatography temperature program started at $80^{\circ} \mathrm{C}$, held for 1 min, and then temperatures were ramped at $20^{\circ} \mathrm{C} / \mathrm{min}$ to $150^{\circ} \mathrm{C}$, then increased $2^{\circ} \mathrm{C} / \mathrm{min}$ to $250^{\circ} \mathrm{C}$, held for $4 \mathrm{~min}$, then increased $30^{\circ} \mathrm{C} / \mathrm{min}$ to $300^{\circ} \mathrm{C}$, and finally held for $6 \mathrm{~min}$, giving a total run time of 66.17 min. In total, $62 \mathrm{PCB}$ congeners or congener pairs or congener triples were separated and quantified (Table 1). Total PCB concentration was calculated as the sum of these congener concentrations, and was reported on a wet weight basis.

The gravimetric method was used to determine lipid concentration of each whole-fish homogenate. A 10-g subsample of the homogenized whole-fish sample was dried with $\mathrm{Na}_{2} \mathrm{SO}_{4}$, twice extracted with dichloromethane/hexane $(4: 1)$ in an ultrasonic bath, evaporated to dryness under a nitrogen stream until a constant weight, and reweighed. Lipid concentrations were expressed on a wet weight basis. Calibration and quality assurance measures included the use of authentic standards, labeled internal standards in every analysis, blanks, duplicates (at a 5\% frequency), standard reference materials, and recovery tests. Detection limits for individual PCB congeners were calculated based on established protocol $[15,19]$, and ranged from 0.001 to $2.000 \mathrm{ng} / \mathrm{g}$ (Table 1). Blanks were clean with the exception of a few congeners (congeners 84, 101, 99, 83, 151, 153 and 180) that were present at trace levels (all below $0.5 \mathrm{ng} / \mathrm{g}$ ). Surrogate recoveries (congener 166) ranged from 81 to $97 \%$. Relative difference between duplicates averaged $11 \%$ for individual PCB congeners and $3 \%$ for total PCB concentration. Determination of the total PCB concentration in reference materials, historically used for Great Lakes fish monitoring [20,21], was within $11 \%$ of the multi-year determination. Drift and linearity checks were also performed with acceptance criterion of $\mathrm{R}^{2}$ above 0.999. For the remainder of this paper, PCB concentration refers to total PCB concentration. Age of each white sucker was estimated by examining thin-sectioned otoliths, following the procedures described by Edwards et al. [22]. This method is considered the most reliable for estimating ages of white suckers [23].

\section{Data analyses}

To determine whether TL, weight, condition, age, or lipid had a significant effect on whole-fish PCB concentration in the white suckers, we considered five analysis of covariance (ANCOVA) models in which $\mathrm{PCB}$ concentration was the dependent variable, sex was the main effect, and TL, weight, Fulton's condition $K$ (equal to weight $\cdot 10^{5} \cdot \mathrm{TL}^{-3}$ ), age, or lipid concentration was the covariate. A key assumption of the ANCOVA model is that the slopes of the regression lines are identical 
Citation: Madenjian CP, Stevens AL, Stapanian MA, Batterman SA, Chernyak SM, et al. (2017) Sex Difference in PCB Concentrations of a Catostomid Fish. J Environ Anal Toxicol 7: 515. doi: 10.4172/2161-0525.1000515

Page 3 of 6

\begin{tabular}{|c|c|c|}
\hline Grouping & PCB congeners & $\begin{array}{l}\text { Range in detection } \\
\text { limits ( } \mathbf{n g} / \mathbf{g})\end{array}$ \\
\hline Tetrachloro & $44,49,52,66,74$, and 77 & $0.016-2.000$ \\
\hline Pentachloro & $\begin{array}{c}82,85,95,99,101,105,107 \\
110,114,118,123, \text { and } 126\end{array}$ & $0.002-0.480$ \\
\hline Hexachloro & $\begin{array}{c}128,131,134,141,146,149 \\
151,156,157, \text { and } 167\end{array}$ & $0.001-0.008$ \\
\hline Heptachloro & $\begin{array}{c}171,172,173,174,175,177 \\
180,183,185,191, \text { and } 193\end{array}$ & $0.003-0.008$ \\
\hline Octachloro & $\begin{array}{c}194,197,199,200,202 \text {, and } \\
205\end{array}$ & $0.003-0.016$ \\
\hline Nonachloro & 206,207, and 208 & $0.006-0.016$ \\
\hline Decachloro & 209 & $0.006-0.006$ \\
\hline Trichloro coelutor pair & $28 / 31$ & $0.720-0.720$ \\
\hline Tetrachloro coelutor pairs & $\begin{array}{c}41 / 71,47 / 48,56 / 60 \text {, and } \\
70 / 76\end{array}$ & $0.080-1.440$ \\
\hline Pentachloro coelutor pair & $81 / 87$ & $0.048-0.048$ \\
\hline Pentachloro coelutor triplet & $84 / 89 / 92$ & $0.080-0.080$ \\
\hline Hexachloro coelutor pairs & $\begin{array}{c}132 / 153,135 / 144 \text {, and } \\
138 / 163\end{array}$ & $0.002-0.003$ \\
\hline $\begin{array}{l}\text { Hexachloro-heptachloro } \\
\text { coelutor pair }\end{array}$ & $137 / 176$ & $0.006-0.006$ \\
\hline Heptachloro coelutor pairs & $170 / 190$ and $182 / 187$ & $0.001-0.006$ \\
\hline
\end{tabular}

Table 1: List of PCB congeners that were detected and quantified in white suckers caught in the Kewaunee River, a tributary to Lake Michigan, during April 2016. The range in detection limits within each PCB congener grouping is also presented. Congeners were numbered according to Ballschmiter et al. [20].

for all levels of the main effect. Therefore, we used an $F$ test for equality of regression lines to determine whether the two regression lines were significantly different from one another. For all of our statistical testing, a was set equal to 0.05 .

We opted to use model averaging to quantify the difference in PCB concentrations between the sexes. Model averaging is a relatively new statistical technique in which a set of parameters are estimated in each of several different model applications to the same data set, and then the estimated values for each of the parameters are averaged by weighting the importance of each of the models by its Akaike weight, w(AIC) [24-26]. Each of the parameters are then assigned the value of the appropriate weighted average. Akaike weights are calculated based on the values of the Akaike information criterion (AIC) calculated for each of the models. One advantage of the model averaging approach is that this approach is not based on the assumption that only one model is the correct model to characterize the data set. Rather, in the model averaging approach, several models may be needed to best characterize the data set. Model averaging is especially appropriate when different models applied to the same data set yield considerably different estimates of the parameter values of interest [24]. We used model averaging to estimate the least square mean value of $\mathrm{PCB}$ concentration in females and the least square mean value of PCB concentration in males. As shown below, we found that neither $K$ nor lipid concentration had a significant effect on PCB concentration $(P>0.29)$. Therefore, only the three ANCOVA model applications with TL, weight, or age as the covariates were used in this model averaging exercise.

\section{Results}

On average, female white suckers were slightly older than male white suckers, whereas females were substantially larger than males (Table 2). Females ranged in age from 9 to 18 years, while age of males ranged from 4 to 24 years. Mean age for females ( 13.3 years) was slightly higher than mean age for males (12.9 years). Females averaged 490 $\mathrm{mm}$ in $\mathrm{TL}$, whereas males averaged $442 \mathrm{~mm}$ in TL. Females averaged

$1298 \mathrm{~g}$ in weight, while males averaged $868 \mathrm{~g}$ in weight (Table 2). On average, lipid concentration of females $(4.9 \%)$ was higher than lipid concentration of males (3.9\%).

Whole-fish PCB concentration of the white suckers significantly varied with TL (ANCOVA: $F=4.32 ; \mathrm{df}=1,48 ; P=0.0430$ ), weight (ANCOVA: $F=5.42 ; \mathrm{df}=1,48 ; P=0.0241$ ), and age (ANCOVA: $F=8.05 ; \mathrm{df}=1,48 ; P=0.0066)$ of the white suckers. In contrast, $\mathrm{PCB}$ concentration was not significantly affected by $K$ (ANCOVA: $F=1.12$; $\mathrm{df}=1,48 ; P=0.2950$ ) or lipid concentration (ANCOVA: $F=1.02 ; \mathrm{df}=1$, 48; $P=0.3169$ ). In all five ANCOVA model applications, the equality of slopes assumption was met. PCB concentration increased with increasing TL (Figure 1), increasing weight (Figure 2), and increasing age (Figure 3 ). The two fitted regression lines were most widely separated in the weight plot, followed by the TL plot, and then by the age plot (Figures 1-3). With weight as the covariate, a significant effect of sex on PCB concentration was detected (ANCOVA: $F=7.36$; $\mathrm{df}=1$, 48; $P=0.0092$ ). Similarly, with TL as the covariate, sex was found to have a significant effect on PCB concentration (ANCOVA: $F=6.09$; $\mathrm{df}=1,48 ; P=0.0172)$. However, with age as the covariate, a significant sex effect was not detected (ANCOVA: $F=2.71 ; \mathrm{df}=1,48 ; P=0.1062$ ).

Of the three ANCOVA model applications included in the model averaging exercise to quantify the difference in $\mathrm{PCB}$ concentrations between the sexes, the ANCOVA model application with age as the covariate explained the highest proportion of variation in $\mathrm{PCB}$ concentration (Table 3). Correspondingly, this model application with age as the covariate had the lowest AIC value and the highest Akaike weight. Model applications with weight and TL as the covariates ranked second and third, respectively, with regard to the proportion of variation in PCB concentration explained by the model (Table 3). Least square mean estimates for females ranged from 172.2 to 190.4 $\mathrm{ng} / \mathrm{g}$, while least square mean estimates for males ranged from 213.6 to $231.1 \mathrm{ng} / \mathrm{g}$. Summing the products of the least square mean and its corresponding Akaike weight across all three ANCOVA models for both females and males yielded weighted average values of 185 and 219 ng/g, respectively (Table 3 ). Thus, on average, adult male white suckers were $18 \%$ higher in PCB concentration than adult female white suckers from the Lake Michigan population that spawns in the Kewaunee River.

\section{Discussion}

The hypothesis that the higher whole-fish PCB concentrations observed in male white suckers compared with female white suckers was due to females undergoing a drastic reduction in whole-fish PCB concentration each year caused by release of eggs at spawning was not supported by the available data. For females to experience a substantial decrease in whole-fish PCB concentration owing to shedding of eggs at spawning, $\mathrm{PCB}$ concentration in white sucker eggs would have to be much higher than PCB concentration in the somatic tissue of the females [1,27]. However, eggs were actually $48 \%$ lower in PCB concentration than the somatic tissue of mature female white

\begin{tabular}{|c|c|c|}
\hline Characteristic & Females & Males \\
\hline Total length $(\mathbf{m m})$ & $490(5)$ & $442(6)$ \\
\hline Weight $(\mathbf{g})$ & $1298(43)$ & $868(33)$ \\
\hline Age (years) & $13.3(0.5)$ & $12.9(0.9)$ \\
\hline Lipid concentration (\%) & $4.9(0.4)$ & $3.9(0.2)$ \\
\hline PCB concentration $\mathbf{( n g / g )}$ & $192(12)$ & $213(9)$ \\
\hline
\end{tabular}

Table 2: Mean values for total length, weight, age, lipid concentration, and PCB concentration, by sex, of the white suckers caught in the Kewaunee River a tributary to Lake Michigan, during April 2016. Standard error of the mean is enclosed within parentheses. Mean values are based on 25 females and 26 males. 


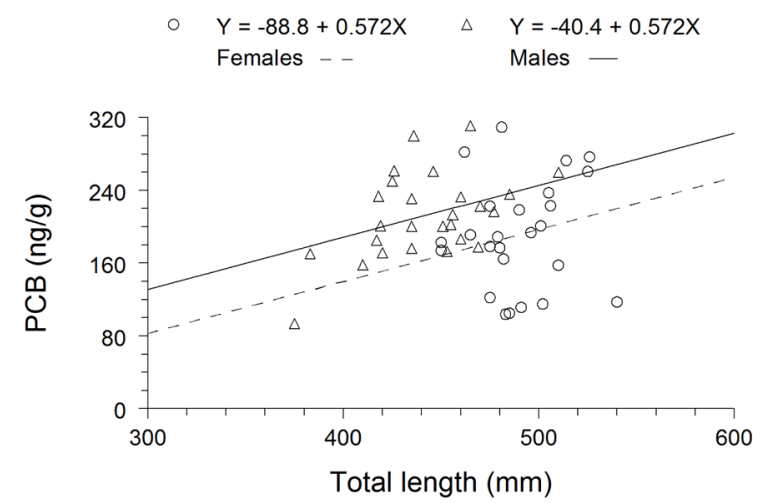

Figure 1: Whole-fish PCB concentration as a function of white sucker total length, by sex. Fitted lines are from application of analysis of covariance (ANCOVA), with whole-fish PCB concentration as the dependent variable, total length as the covariate, and sex as the main effect. These white suckers were caught in the Kewaunee River, a tributary to Lake Michigan, during April 2016.

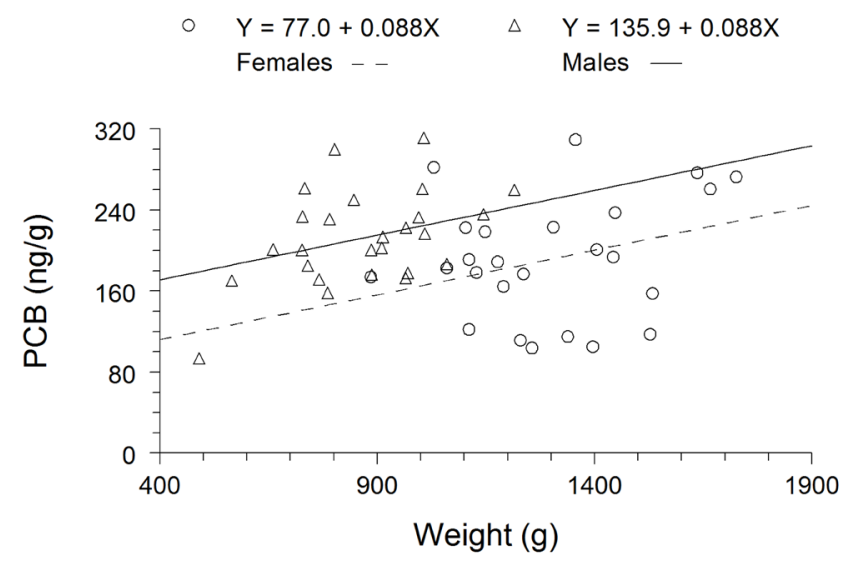

Figure 2: Whole-fish PCB concentration as a function of white sucker weight, by sex. Fitted lines are from application of analysis of covariance (ANCOVA), with whole-fish PCB concentration as the dependent variable, weight as the covariate, and sex as the main effect. These white suckers were caught in the Kewaunee River, a tributary to Lake Michigan, during April 2016.

suckers from Lake Ontario [27]. Consequently, PCB concentration of female white suckers was expected to increase by $9.1 \%$ immediately after spawning due to release of eggs. Because PCB concentration of female white suckers was expected to increase after shedding of eggs at spawning, this shedding of eggs effect could not possibly contribute, at any level, to the higher PCB concentrations observed in male white suckers.

The hypothesis that higher lipid concentrations in males caused the higher whole-fish PCB concentration in males was also not supported by the available data. First, we found that female white suckers were actually higher in lipid concentration than male white suckers. Second, research results over the past four decades have indicated that food consumption, rather than lipid concentration, drives PCB accumulation in fish [2,28-31]. Lipid concentration of females was greater than that of males in walleye from South Manistique Lake, sea lamprey from Lake Huron, burbot from Great Slave Lake, cisco from Lake Superior, and lake whitefish from Lake Huron, while males exceeded females in lipid concentration in lake trout from Lake Ontario, coho salmon from Lake Michigan, burbot from Lake Erie, and summer flounder from New Jersey coastal waters

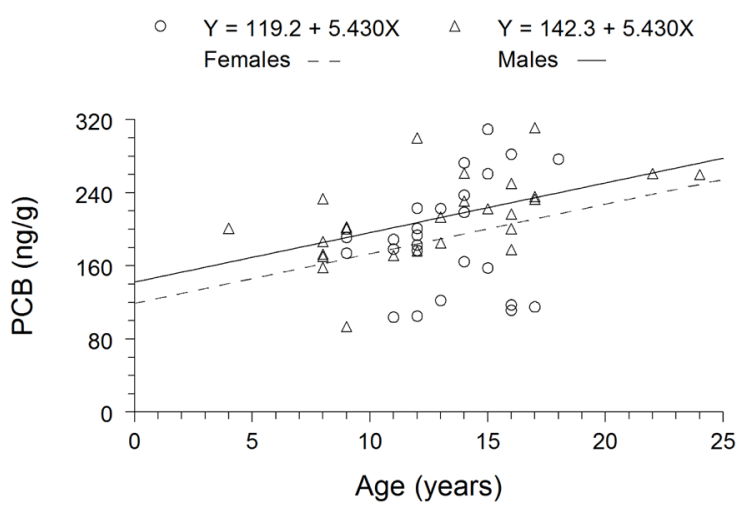

Figure 3: Whole-fish PCB concentration as a function of white sucker age by sex. Fitted lines are from application of analysis of covariance (ANCOVA), with whole-fish PCB concentration as the dependent variable, age as the covariate, and sex as the main effect. These white suckers were caught in the Kewaunee River, a tributary to Lake Michigan, during April 2016.

\begin{tabular}{|c|c|c|c|}
\hline $\begin{array}{c}\text { Characteristic of ANCOVA } \\
\text { model application }\end{array}$ & $\begin{array}{c}\text { Model with } \\
\text { total length as } \\
\text { covariate }\end{array}$ & $\begin{array}{c}\text { Model with } \\
\text { weight as } \\
\text { covariate }\end{array}$ & $\begin{array}{c}\text { Model with age } \\
\text { as covariate }\end{array}$ \\
\hline $\mathbf{R}^{\mathbf{2}}$ & 0.118 & 0.136 & 0.176 \\
\hline AIC & 406.0 & 405.0 & 402.5 \\
\hline $\mathbf{w}$ (AIC) & 0.118 & 0.200 & 0.682 \\
\hline $\begin{array}{c}\text { Least square mean of PCB } \\
\text { concentration (ng/g) in } \\
\text { females }\end{array}$ & 177.6 & 172.2 & 190.4 \\
\hline $\begin{array}{c}\text { Least square mean of PCB } \\
\text { concentration (ng/g) in } \\
\text { males }\end{array}$ & 226.0 & 231.1 & 213.6 \\
\hline
\end{tabular}

Table 3: Use of model averaging to quantify the difference in PCB concentrations between the sexes of white suckers caught in the Kewaunee River, a tributary to Lake Michigan, during April 2016. Analysis of covariance (ANCOVA) was used in each of the three model applications, with PCB concentration as the dependent variable, sex as the main effect, and total length, weight, or age as the covariate. $\mathrm{R}^{2}$ denotes the proportion of variation in $\mathrm{PCB}$ concentration explained by the ANCOVA model. AIC denotes the Akaike information criterion, and $\mathrm{W}(\mathrm{AIC})$ denotes the Akaike weight of the ANCOVA model. AIC was corrected for small sample size. Weighting the least square means by $w(A I C)$, the weighted average PCB concentration of females was equal to $185 \mathrm{ng} / \mathrm{g}$ and the weighted average PCB concentration of males was equal to $219 \mathrm{ng} / \mathrm{g}$.

[1]. Moreover, our results showed that females exceeded males in lipid concentration of Lake Michigan white suckers that spawn in the Kewaunee River. Yet, in all 10 fish populations, males exceeded females in PCB concentration from 17 to $43 \%$. Thus, relative differences in lipid concentrations between the sexes were unrelated to relative differences in PCB concentrations between the sexes.

We conclude that the primary driver of the higher $\mathrm{PCB}$ concentrations in male white suckers than in female white suckers was most likely a higher rate of energy expenditure by males compared with females. In the few studies that have investigated differences in swimming activity or resting metabolic rate (or standard metabolic rate (SMR)) between the sexes of fish, males have been shown to have the higher swimming activity and higher SMR [1]. Similarly, in the few studies examining differences in physical activity or SMR between the sexes of higher vertebrates, higher physical activity and higher SMR have been demonstrated in males compared with females. Both higher activity and higher SMR contribute to a higher rate of energy expenditure [1]. In turn, this higher rate of energy expenditure leads to 
a higher rate of food consumption by males. Rate of PCB accumulation increases with increasing rate of food consumption. Thus, higher PCB concentrations in male white suckers compared with female white suckers was likely primarily driven by a higher rate of energy expenditure in males compared with females.

The growth dilution effect may also have contributed to the observed higher PCB concentration in males than in females. Although mean age of females was similar to mean age of males in our sample of white suckers from the Lake Michigan population that spawns in the Kewaunee River, females were substantially larger than males, indicating considerably faster growth by females. Indeed, faster growth by females compared with that by males appears to be a prevalent characteristic in white sucker populations [32]. Bioenergetics modeling is needed to quantify the growth dilution effect [1]. Unfortunately, bioenergetics models for catostomid fishes are not yet available [33]. Moreover, to the best of our knowledge, a detailed study on the seasonal diet composition of white suckers in Lake Michigan has yet to be completed. For both walleye from South Manistique Lake and summer flounder from the New Jersey coast, females grew substantially faster than males, and the growth dilution effect made a substantial contribution to the higher PCB concentrations observed in males compared with females, although the higher energy expenditure in males was still considered the primary driver of the sex difference in PCB concentrations [1]. In contrast, for both lake whitefish from Lake Huron and burbot from Lake Erie, females grew considerably faster than males, yet bioenergetics modeling results indicated that the growth dilution effect was practically negligible. Thus, the higher $\mathrm{PCB}$ concentrations in males compared with females for both the lake whitefish and burbot populations appeared to be almost entirely driven by the difference in energy expenditure rates between the sexes [1]. In light of these findings, a sex difference in energy expenditure rates was likely the predominant factor accounting for the observed difference in PCB concentrations between the sexes of Lake Michigan white suckers that spawn in the Kewaunee River.

A difference in habitat use or in diet composition between the sexes could potentially explain the observed difference in PCB concentrations between the sexes of Lake Michigan white suckers, but this hypothesis was not supported by the available data. A difference in carbon and nitrogen stable isotope ratios between the sexes may signal a difference in habitat utilization and/or a difference in food habits between the sexes $[1,18,34]$. However, in an earlier study, carbon and nitrogen stable isotope ratios were shown not to significantly vary between the sexes of Lake Michigan white suckers that spawn in the Kewaunee River [35], suggesting that this hypothesis was invalid.

Degree of PCB contamination in Lake Michigan white suckers that spawn in the Kewaunee River was relatively low compared with that for white sucker populations from aquatic ecosystems heavily contaminated with PCBs, but was higher than that for white suckers from aquatic ecosystems lacking any point source inputs of PCBs. We estimated that whole-fish PCB concentrations of Lake Michigan adult white suckers that spawn in the Kewaunee River averaged about $200 \mathrm{ng} / \mathrm{g}$. In stark contrast, white suckers from three reaches of the Housatonic River in Massachusetts and Connecticut, USA, averaged between 12000 and $72000 \mathrm{ng} / \mathrm{g}$ in PCB concentration [36]. The Housatonic River has been heavily contaminated with PCBs from industrial activity centered at Pittsfield, Massachusetts. White suckers sampled for the Housatonic River study ranged in age from 6 to 21 years [36], which was similar to the range of ages of 4 to 24 years for white suckers used in our study of the Lake Michigan population.
In a study of $\mathrm{PCB}$ concentrations in white suckers from eight river tributaries to the Gulf of Maine in Maine, USA, Mierzykowski [37] reported that $\mathrm{PCB}$ concentration of the white suckers in the seven river tributaries lacking any known point source inputs of PCBs was below the detection limit of $10 \mathrm{ng} / \mathrm{g}$ in 22 of the 28 samples analyzed. In the remaining river tributary with a known $\mathrm{PCB}$ point source input, white sucker PCB concentration averaged $41 \mathrm{ng} / \mathrm{g}$. Although white suckers were not aged in the Mierzykowski [37] study, mean TL of white suckers used in this study was only $211 \mathrm{~mm}$, which was less than half of the mean TL of $465 \mathrm{~mm}$ for white suckers used in our study. Lake Michigan has received point source inputs of PCBs, but PCB concentrations of Lake Michigan fishes have decreased by more than an order of magnitude between 1970 and 2010, and this decrease was attributable, at least in part, to the ban imposed during the $1970 \mathrm{~s}$ on use of PCBs in the USA [21,38].

Our findings will be useful to fishery managers establishing fish consumption advisories for white suckers from Lake Michigan. White suckers are eaten by people in the Laurentian Great Lakes region [39]. Typically, white suckers are pickled, canned, smoked, or deep fried in preparation for consumption. Another preparation method involves grinding the fillets to make patties or fish cakes. Recreational fisheries for white suckers are fairly popular in tributaries to the Laurentian Great Lakes. In addition, small commercial fisheries for white suckers operate within the Laurentian Great Lakes [39]. Mean and maximum whole-fish PCB concentrations of the white suckers from our study were 202 and 311 ng/g, respectively. The U. S. Food and Drug Administration (FDA) threshold for PCB concentration in fish consumed by people is 2000 ng/g [40]. Thus, all of the white sucker PCB concentrations were well below the FDA guideline. Moreover, whole-fish PCB concentrations typically exceed fillet PCB concentrations in fish [41]. Consequently, fillet PCB concentrations in white suckers would be expected to be even further below the FDA guideline than whole-fish PCB concentrations in white suckers.

\section{Conclusion}

Whole-fish PCB concentration of mature white suckers caught during the spring spawning run in the Kewaunee River, a tributary to Lake Michigan, significantly increased with increasing TL, increasing weight, and increasing age of the white suckers. Based on a model averaging approach, mean whole-fish PCB concentration of these white suckers was $185 \mathrm{ng} / \mathrm{g}$ for females and $219 \mathrm{ng} / \mathrm{g}$ for males. Thus, on average, males were $18 \%$ higher in PCB concentration than females. This difference in PCB concentration between the sexes was most likely primarily attributable to a higher rate of energy expenditure by males than by females. Higher whole-fish PCB concentration in males than in females has now been documented in nine species of fish, with white sucker being the only omnivore of the nine species. Given these findings, this characteristic of males exceeding females in whole-fish PCB concentration, presumably due to a higher energy expenditure rate, appears to be widespread among fish populations around the world. PCB concentrations in the white suckers were relatively low, well below the FDA guideline, and our results will be useful to fishery managers developing fish consumption advisories for Lake Michigan white suckers.

\section{Acknowledgments}

Martin Perales assisted with the field work in the Kewaunee River; Tim Desorcie and Lynn Ogilvie assisted with homogenization of the fish; and Bill Edwards aged the fish. Dave Clapp reviewed the manuscript and made helpful suggestions for its improvement. Use of trade, product, or firm names does not imply endorsement by the United States Government. 
Citation: Madenjian CP, Stevens AL, Stapanian MA, Batterman SA, Chernyak SM, et al. (2017) Sex Difference in PCB Concentrations of a Catostomid Fish. J Environ Anal Toxicol 7: 515. doi: 10.4172/2161-0525.1000515

Page 6 of 6

\section{References}

1. Madenjian CP, Rediske RR, Krabbenhoft DP, Stapanian MA, Chernyak SM, et al. (2016) Sex differences in contaminant concentrations of fish: a synthesis. Biology of Sex Differences 7: 42.

2. Weininger D (1978) Accumulation of PCBs by lake trout in Lake Michigan. Ph.D. dissertation, University of Wisconsin, Madison, WI, USA.

3. Munkittrick KR, Dixon DG (1989) Use of white sucker (Catostomus commersoni) populations to assess the health of aquatic ecosystems exposed to low-level contaminant stress. Canadian Journal of Fisheries and Aquatic Science 46: $1455-1462$.

4. Servos MR, Casey JH, Ferguson ML, Van Der Kraak G, Ferguson H, et al (1992) Impact of modernized bleach kraft mill on white sucker populations in the Spanish River, Ontario. Water Pollution Research Journal of Canada 27: 423-427.

5. Cooke SJ, Bunt CM, Hamilton SJ, Jennings CA, Pearson MP, et al. (2005) Threats, conservation strategies, and prognosis for suckers (Catostomidae) in North America: insights from regional case studies of diverse family of nongame fishes. Biological Conservation 121: 317-331.

6. Miller LL, Rasmussen JB, Palace VP, Hontela A (2009) Physiological stress response in white suckers from agricultural drain waters containing pesticides and selenium. Ecotoxicology and Environmental Safety 72: 1249-1256.

7. Doherty CA, Curry RA, Munkittrick KR (2010) Spatial and temporal movements of white sucker: implications for use as a sentinel species. Transactions of the American Fisheries Society 139: 1818-1827.

8. Blazer VS, Hoffman J, Walsh HL, Braham RP, Hahn C, et al. (2014) Health of white sucker within the St. Louis River area of concern associated with habitat usage as assessed using stable isotopes. Ecotoxicology 23: 236-251.

9. Blazer VS, Walsh HL, Braham RP, Hahn CM, Mazik P, et al. (2017) Tumours in white suckers from Lake Michigan tributaries: pathology and prevalence. Journal of Fish Diseases 40: 377-393.

10. Childress ES, Allan JD, McIntyre PB (2014) Nutrient subsidies from iteroparous fish migrations can enhance stream productivity. Ecosystems 17: 522-534.

11. Doosey $\mathrm{MH}$, Bart $\mathrm{HL}$ (2011) Morphological variation of the palatal organ and chewing pad of Catostomidae (Teleostei: Cypriniformes). Journal of Morphology 272: 1092-1108.

12. Stewart NH (1926) Development, growth, and food habits of the white sucker, Catostomus commersonii Lesueur. Bulletin of the Bureau of Fisheries 42: 147-184.

13. Saint-Jacques N, Harvey HH, Jackson DA (2000) Selective foraging in the white sucker (Catostomus commersoni). Canadian Journal of Zoology 78 : 1320-1331.

14. American Fisheries Society (2004) Guidelines for the use of fishes in research Available at: https://fisheries.org/docs/policy_useoffishes.pdf (accessed on 1 September 2017).

15. Schmidt LJ (1997) Analysis of total PCBs and PCB congeners and transnonachlor in fish by gas chromatography/negative chemical ionization single ion mass spectrometry. Lake Michigan Mass Balance Study (LMMB) methods compendium. Volume 2: Organic and mercury sample analysis techniques. U. S. Environmental Protection Agency, Great Lakes National Program Office, Chicago, IL, USA, EPA 905-R-97-012b.

16. Schmidt LJ (1997) Extraction and lipid separation of fish samples for contaminant analysis and lipid determination. Lake Michigan Mass Balance Study (LMMB) methods compendium. Volume 2: Organic and mercury sample analysis techniques. U. S. Environmental Protection Agency, Great Lakes National Program Office, Chicago, IL, USA, EPA 905-R-97-012b.

17. Cherynak SM, Rice CP, Quintal RT, Begnoche LJ, Hickey JP, et al. (2005) Time trends (1983-1999) for organochlorines and polybrominated diphenyl ethers in rainbow smelt (Osmerus mordax) from Lakes Michigan, Huron, and Superior, USA. Environmental Toxicology and Chemistry 24: 1632-1641.

18. Madenjian CP, Yule DL, Chernyak SM, Begnoche LJ, Berglund EK, et al. (2014) Males exceed females in PCB concentrations of cisco (Coregonus artedi) from Lake Superior. Science of the Total Environment 493: 377-383.

19. U. S. Environmental Protection Agency (2008) Method 1668B: Chlorinated biphenyl congeners in water, soil, sediment, biosolids, and tissue by HRGC/ HRMS. Office of Water, Washington, DC, USA, EPA-821-R-08-020.

20. Ballschmiter K, Bacher R, Mennel A, Fischer R, Riehle U, et al. (1992) The determination of chlorinated biphenyls, chlorinated dibenzodioxins, and chlorinated dibenzofurans by GC-MS. Journal of High Resolution Chromatography 15: 260-270.

21. Hickey JP, Batterman SA, Chernyak SM (2006) Trends of chlorinated organic contaminants in Great Lakes trout and walleye from 1970 to 1998. Archives of Environmental Contamination and Toxicology 50: 97-110.

22. Edwards WH, Stapanian MA, Stoneman AT (2011) An evaluation of precision in age estimation of two treatments of otoliths from an aging burbot population. Journal of Applied Ichthyology 27(Supplement 1): 43-48.

23. Sylvester RM, Berry CR Jr (2006) Comparison of white sucker age estimates from scales, pectoral fin rays, and otoliths. North American Journal of Fisheries Management 26: 24-31.

24. Hoeting JA, Madigan D, Raftery AE, Volinsky CT (1999) Bayesian mode averaging: a tutorial. Statistical Science 14: 382-401.

25. Link WA, Barker RJ (2006) Model weights and the foundation of multimode inference. Ecology 87: 2626-2635.

26. Burnham KP, Anderson DR, Huyvaert KP (2011) AIC model selection and multimodel inference in behavioral ecology: some background, observations, and comparisons. Behavioral Ecology and Sociobiology 65: 23-35.

27. Niimi AJ (1983) Biological and toxicological effects of environmental contaminants in fish and their eggs. Canadian Journal of Fisheries and Aquatic Sciences 40: 306-312.

28. Borgmann U, Whittle DM (1991) Contaminant concentration trends in Lake Ontario lake trout (Salvelinus namaycush): 1977 to 1988. Journal of Great Lakes Research 17: 368-381.

29. Borgmann U, Whittle DM (1992) Bioenergetics and PCB, DDE, and mercury dynamics in Lake Ontario lake trout (Salvelinus namaycush): a model based on surveillance data. Canadian Journal of Fisheries and Aquatic Sciences 49: 1086-1096.

30. Stow CA, Jackson LJ, Amrhein JE (1997) An examination of the PCB:lipid relationship among individual fish. Canadian Journal of Fisheries and Aquatic Sciences 54: 1031-1038.

31. Visha A, Ghandi N, Bhavsar SP, Arhonditsis GB (2015) A Bayesian assessment of the mercury and PCB temporal trends in lake trout (Salvelinus namaycush) and walleye (Sander vitreus) from Lake Ontario, Ontario, Canada. Ecotoxicology and Environmental Safety 117: 174-186.

32. Scott WB, Crossman EJ (1973) Freshwater fishes of Canada. Fisheries Research Board of Canada Bulletin 184

33. Deslauriers D, Chipps SR, Breck JE, Rice JA, Madenjian CP (2017) Fish Bioenergetics 4.0: An R-based modeling application. Fisheries 42: in press.

34. Madenjian CP, Jensen OP, Rediske RR, O'Keefe JP, Vastano AR, et al. (2016) Differences in energy expenditures and growth dilution explain higher PCB concentrations in male summer flounder. PLOS ONE 11: e0147223.

35. Stevens AL (2016) Mercury in Wisconsin fishes: pathological and consumption implications. M.S. thesis, University of Wisconsin, Madison, WI, USA.

36. Coles JF (1999) Length-age relations and PCB content of mature white suckers from the Connecticut and Housatonic River basins. Northeastern Naturalist 6: 263-275.

37. Mierzykowski SE (2007) Contaminant assessment of white suckers form eight rivers in the Gulf of Maine Distinct Population Segment for Atlantic salmon. U. S. Fish and Wildlife Service, Maine Field Office, Old Town, ME, USA, Special Project Report FY07-MEFO-1-EC.

38. Rasmussen PW, Schrank C, Williams MCW (2014) Trends of PCB concentrations in Lake Michigan coho and chinook salmon, 1975-2010. Journal of Great Lakes Research 40: 748-754

39. Michigan Department of Natural Resources (2012) Michigan suckers are popular with spring anglers. Michigan Department of Natural Resources, Lansing, MI, USA. Available at: http://www.michigan.gov/dnr/0,4570,7-153-275299--RSS,00.html (accessed on 1 September 2017).

40. United States Food and Drug Administration (2015) Tolerances of polychlorinated biphenyls (PCBs), 21 CFR Ch. 1, April 1, 2015, Sec. 109.30(a) (7). Health and Human Services, Public Health Service, Rockville, MD, USA.

41. Amrhein JF, Stow CA, Wible C (1999) Whole-fish versus filet polychlorinatedbiphenyl concentrations: an analysis using classification and regression tree models. Environmental Toxicology and Chemistry 18: 1817-1823. 